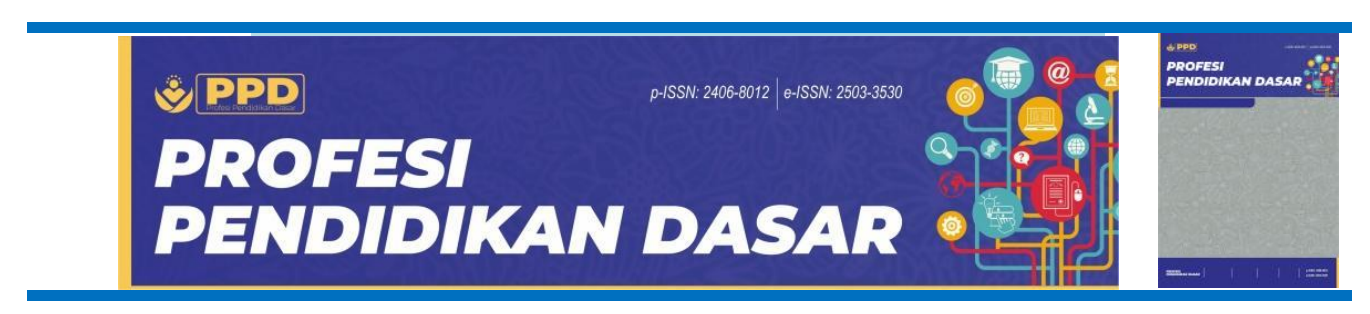

\title{
Which Factor Influences Environmental Care Characters More: Knowledge of Issue or Demographic Factors?
}

\author{
Azmi Al Bahij", Nidar Yusuf, Lativa Qurrotaini, Khairadha Maharani* \\ Universitas Muhammadiyah Jakarta, Jakarta, Indonesia \\ *Email: khairadhamaharani@gmail.com
}

Submitted: 2021-03-16

DOI: $10.23917 / p p d . v 8 i 2.13940$

Accepted: 2021-12-23

Published: 2021-12-30

\begin{tabular}{|c|c|}
\hline Keywords: & Abstract \\
\hline $\begin{array}{l}\text { character of } \\
\text { environmental } \\
\text { care }\end{array}$ & $\begin{array}{l}\text { The background of this research was due to the lack of people's awareness to } \\
\text { their environment. A report by Indonesian Central Statistics Agency in } 2018 \\
\text { stated that the Indonesian Environmental Ignorance Behavior Index (IPKLH) in } \\
2018 \text { is } 0.72 \text {. The number indicates a high level of ignorance on waste } \\
\text { management. That being said, the character of environmental care in society is } \\
\text { still low. Therefore, the researcher was moved to study the influence of } \\
\text { knowledge issues and demographic factors on environmental care for } \\
\text { elementary school students. A quantitative survey was utilized as a research } \\
\text { methodology. In this study, } 119 \text { people were included as a sample. Of the } \\
\text { questionnaire instrument for the character of environmental care, the } \\
\text { researcher had adjusted to the life of elementary school students. The } \\
\text { questionnaire instrument was then analyzed using SPSS version } 22.0 \text { with } \\
\text { simple regression technique and multiple regression. The result showed that the } \\
\text { significant value obtained by all variables is } 0.001 \text { or P < } 0.05 \text {. That being said, } \\
\text { Ha wa accepted, and Ho was rejected, or it displays that there was an influence } \\
\text { between each of them. The percentage obtained respectely is } 4.4 \% \text { and } 9.4 \% \text {. }\end{array}$ \\
\hline
\end{tabular}

\section{INTRODUCTION}

\section{Background}

The environment is the things around us that can affect our lives. Our lives as humans will not be separated from interactions with the environment (Wiryono, 2013). The environment is an element that affects life because maintaining the environment will positively impact human life. Environmental quality depends on human attitudes and

(C) The Author(s). 2021

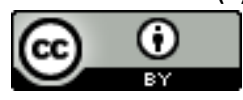

This work is licensed under a Creative Commons Attribution 4.0 International License 
behavior towards the environment itself (Palupi dan Sawitri, 2017: 214). Environmental issues are part of a severe global problem felt by humans, which is increasing day by day (Fua, 2014: 20). The lack of human awareness of environmental conditions is one of the causes. The environment is still not considered important, while environmental damage has occurred everywhere and was followed by natural disasters that caused many victims.

Environmental changes due to human activities will make our earth unfriendly, which is a threat to human life. Limited knowledge about environmental issues tends to be the reason humans continue to destroy the environment. One of the triggering factors for environmental damage is human ignorance in maintaining, managing and protecting the environment and ignorance about the consequences of their actions on the environment, such as throwing garbage in any place that can pollute the environment. This is often considered normal because there are no binding rules for this (Purba and Yunita, 2017).

From an Islamic perspective, humans and the environment have a close relationship because Allah created this world in balance and harmony, including humans and the environment. This balance and harmony must be maintained not to damage the environment. The continuity of life in nature is interrelated, and if one component is damaged, it will affect the other components (Harahap, 2015: 5).

\section{Problem of Study}

The waste management component has an index of 0.72 in the Index Value Based on the Dimensions of Compiling the Environmental Indifference Behavior Index in Indonesia, according to the 2018 Indonesia Environmental Ignorance Behavior Index study. The index number indicates that waste management is poorly understood in Indonesia. (Indonesian Central Statistics Agency, 2018). According to the above-mentioned article, World Bank estimates from 2012 suggest that Indonesia generates 85 thousand tons of garbage every day. This figure is expected to rise to 150 thousand tons per day by 2025 . The landfill in Indonesia in 2016 is estimated to be 65.2 million tons per year based on garbage generated. Plastic trash accounts for $16 \%$ of that total, or around 10 million tons every year. (Ministry of Finance of the Republic of Indonesia, 2019).

\section{State of the Art}

These circumstances highlight the significance of instilling the value of environmental stewardship in the next generation. Concern for the environment must be instilled in primary school pupils at a young age in order for it to become a positive habit in the future (Narut and Nardi, 2019). This awareness for the environment can begin in school with students developing the habit of throwing garbage in its proper place, caring for plants, maintaining the cleanliness of the classroom and school environment, and a variety of other activities. If this is done repeatedly, students will develop a caring attitude toward the environment (Narut and Nardi, 2019).

Environmental awareness is influenced by environmental knowledge and understanding, as well as demographic factors. In line with this, demographic factors such as education, gender, age, income, and place of residence are directly related to the nature of environmental care (Pronityastuti, 2017: 23). Age, education, type of work, and gender are all demographic variables. Demographic variables such as age and gender have the most significant influence on changes in population composition (Aryogi \& Wulansari, 2016). Researchers used two demographic variables in this study: age and gender. 


\section{Gap Study \& Objective}

These findings are consistent with what researchers discovered at the Lab School Elementary School, Faculty of Education, Universitas Muhammadiyah Jakarta, where students' environmental awareness is still low. Students' concern and self-awareness about the importance of environmental preservation can help to create a healthy and comfortable school environment. A healthy and comfortable school environment will make learning more enjoyable. School is a place to instill environmental stewardship in students. Based on the foregoing, the researcher believes that it is critical to investigate and demonstrate the existence of the influence of knowledge of issue and demographic factors on the character of students' environmental care.

\section{METHODS}

This study employs a quantitative approach, as well as a survey method. Because the study wants to test the hypothesis about how much knowledge of issues and demographic factors influence elementary school students' environmental care character, the researcher employs a quantitative approach with a survey method. The survey method was chosen by the researchers due to its cost-effectiveness and speed in presenting research findings. This study lasted one month, from July to August of 2020. 119 students in grades 4, 5, and 6 were used as subjects. The character of environmental care is the dependent variable in this study. Then there are independent variables such as knowledge of issue and demographic factors. In this study, data was gathered through the use of a questionnaire (questionnaire) and test methods. The research instrument used is a questionnaire to collect data on the character of environmental care, and the test instrument is multiple-choice questions to collect data on knowledge of issues or knowledge about environmental issues. The data analysis method used in this study is a simple regression technique using SPSS.

Table 1. Instrument of Environmental Care Character Measurement

\begin{tabular}{llcc}
\hline \multicolumn{1}{c}{ Dimension } & \multicolumn{1}{c}{ Indicators } & \multicolumn{2}{c}{ Question Item } \\
\cline { 2 - 4 } & & $(+)$ & $(-)$ \\
\hline Waste & Garbage Disposal & $1,2,3$ & $4,5,6$ \\
\cline { 2 - 4 } management & Cleaning the school environment & 7,8, & 12 \\
& & $9,10,11$ & \\
\cline { 2 - 4 } & Tidying up the classroom and school & 13, & 14, \\
& & 15,16 & 17 \\
\hline Water saving & Energy and water saving & 18,19 & - \\
efforts & & & 23,24, \\
\hline Energy Saving & Energy and water saving & $20,21,22$ & 28,29 \\
\hline $\begin{array}{l}\text { Caring for } \\
\text { Surroundings } \\
\text { Environment }\end{array}$ & Maintaining the school garden & 26,27 & - \\
\cline { 2 - 4 } & Participate in activities to keep the & 30 & \\
\hline
\end{tabular}


Table 2. Instrument of Knowledge of Issue Measurement

\begin{tabular}{|c|c|c|c|}
\hline \multirow[b]{2}{*}{ Dimension } & \multirow[b]{2}{*}{ Indicators } & \multicolumn{2}{|c|}{ Question Item } \\
\hline & & $\begin{array}{l}\text { Question } \\
\text { Number }\end{array}$ & $\begin{array}{l}\text { Amount of } \\
\text { Item }\end{array}$ \\
\hline \multirow[t]{2}{*}{$\begin{array}{l}\text { Factual (basic } \\
\text { information) }\end{array}$} & Knowledge of Terminology & $\begin{array}{c}1,2 \\
3\end{array}$ & 3 \\
\hline & Knowledge of Special Elements & 4,5 & 2 \\
\hline \multirow{3}{*}{$\begin{array}{l}\text { Conceptual (the } \\
\text { relationship } \\
\text { between the parts } \\
\text { of a structure) }\end{array}$} & $\begin{array}{l}\text { Knowledge of classifications and } \\
\text { categories }\end{array}$ & $\begin{array}{c}6,7,8 \\
9,10\end{array}$ & 5 \\
\hline & $\begin{array}{l}\text { Knowledge of principles and } \\
\text { generalizations }\end{array}$ & $\begin{array}{l}11,12 \\
13,14 \\
\end{array}$ & 4 \\
\hline & $\begin{array}{l}\text { Knowledge of various theories, } \\
\text { models and structures }\end{array}$ & 15,16 & 2 \\
\hline $\begin{array}{l}\text { Procedural (how } \\
\text { to position oneself } \\
\text { to do something) }\end{array}$ & Knowledge of various special skills & 5,22 & 2 \\
\hline \multirow[t]{2}{*}{$\begin{array}{l}\text { Metacognitive } \\
\text { (think in general } \\
\text { and in particular) }\end{array}$} & $\begin{array}{l}\text { Knowledge of various cognitive } \\
\text { tasks, including contextual } \\
\text { knowledge }\end{array}$ & $\begin{array}{l}23,24 \\
25\end{array}$ & 3 \\
\hline & Self-Knowledge & $\begin{array}{c}26,27 \\
28,29 \\
30\end{array}$ & 5 \\
\hline
\end{tabular}

Table 2 explains that the four dimensions of environmental care that are evaluated are: 1) waste management; 2 ) water conservation efforts; 3 ) energy conservation efforts; and 4) environmental maintenance. Students must respond to 30 statements on the questionnaire. Table 2 also explains that issue knowledge is evaluated on four dimensions: 1) factual (basic information); 2) conceptual (relationships between the parts of a structure); 3) procedural (how to position to do something); and 4) metacognitive (knowledge of how to position to do something) (thinking in general and specifically). A total of 30 items make up the test instrument used to assess knowledge of the topic.

\section{RESULTS}

In quantitative survey research, a prerequisite test is performed first to demonstrate that the data variance is the same or homogeneous, followed by a homogeneity test using the SPSS program. Using Levene Statistics, a homogeneity test was performed. A summary of the homogeneity test is provided in Table 3. 
Bahij et al - Which Factor Influences Environmental ...

Table 3. Homogeneity Test Results

\begin{tabular}{ccccc} 
& Levene Statistic & df1 & df2 & Sig. \\
\hline $\begin{array}{c}\text { Knowledge } \\
\text { of Issue }\end{array}$ & 2.252 & 9 & 109 & 0,124 \\
$\begin{array}{c}\text { Gender } \\
\text { Age }\end{array}$ & 0,679 & 1 & 117 & 0,411 \\
\hline
\end{tabular}

Based on the output, the homogeneity test results are known to have a significance value of the knowledge of issue variable $\left(X_{1}\right)$ on the environmental care character variable $(Y)$ of $0.124>0.05$, indicating that it is homogeneous. The test results on the variable $\left(X_{2 \cdot 1}\right)$ gender to the variable $(Y)$ environmental care character, namely $0.411>0.05$, suggest that it is homogeneous. The test results on the variable $\left(\mathrm{X}_{2 \cdot 2}\right)$ age on the character of caring for the environment, namely $0.140>0.05$, indicate that the data variance is homogeneous.

The normality test, which is used to determine whether or not the data in this study is normally distributed, is the second prerequisite test. The Kolmogorov-Smirnov test is used to determine normality. The following table shows the SPSS output results for the data normality test.

Table 4. Normality Test Result

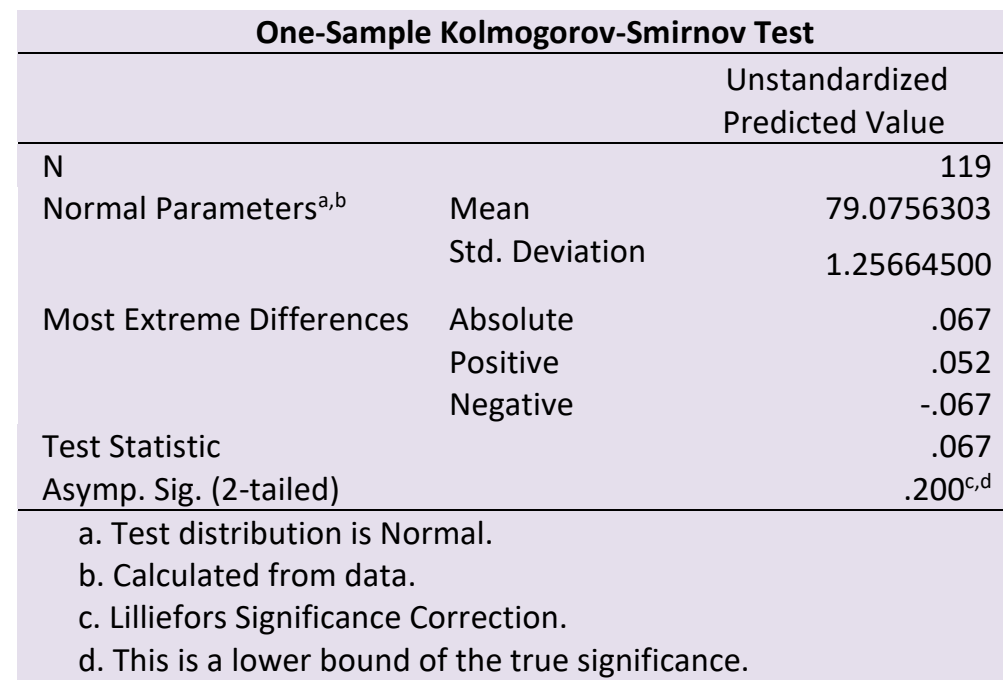

Based on the Table 4, the significance value is greater than 0.05 , namely $0.200>0.05$, implying that the data in the study were normally distributed. After passing the prerequisite test, the data must be analyzed. Simple regression analysis was used to determine which factors have the greatest influence on the character of environmental care. The following is a summary of the data analysis results obtained using the SPSS program. 
Table 5. Simple Regression Test Results $X_{1}$ and $Y$

\begin{tabular}{llllr}
\multicolumn{5}{c}{ Model Summary } \\
\hline Model & $\mathrm{R}$ & Square & $\begin{array}{l}\text { Adjusted R } \\
\text { Square }\end{array}$ & $\begin{array}{c}\text { Std. Error of } \\
\text { the Estimate }\end{array}$ \\
\hline 1 & $.209^{\text {a }}$ & .044 & .035 & 5.398 \\
\hline a. Predictors: (Constant), Knowledge of Issue \\
b. Dependent Variable: Environmental Care
\end{tabular}

According to the SPSS "Model Summary" output table above, the coefficient or R-value is 0.209 , and the $R$ square value or coefficient of determination obtained is 4.4 percent, indicating that the knowledge of variable $X_{1}$ has a 4.4 percent effect on the environmental care variable $(\mathrm{Y})$.

Table 6. Simple Regression Test Results $X_{2}$ and $Y$

\begin{tabular}{llcrr}
\multicolumn{8}{c}{ Model Summary } \\
\hline Model & R & R Square & $\begin{array}{l}\text { Adjusted R } \\
\text { Square }\end{array}$ & $\begin{array}{c}\text { Std. Error of } \\
\text { the Estimate }\end{array}$ \\
\hline 1 & $.306^{\text {a }}$ & .094 & .078 & 5.530 \\
\hline a. Predictors: (Constant), Age, Gender & &
\end{tabular}

The global coefficient value $(R)$ in the output above is 0.306 , indicating a sufficient and unidirectional relationship between the character of caring for the environment, gender, and age. Gender and age variables explain 9.4 percent of the variation in environmental care character variables.

\section{DISCUSSION}

The results of the analysis show that there is a significant influence between knowledge of issue variables and demographic factors on the character of environmental care. The data from the analysis of issue variables on the character of environmental care show a 4.4 percent influence between the two. It is understandable that there is a slight relationship between knowledge and the character of environmental care. This is in line with the opinion of Kaiser et al., (1999), that several previous studies found statistically less significant results, but that knowledge of issue played a role both directly and indirectly.

This is consistent with Molina et al (2018)'s belief that knowledge, attitudes, perceptions, and effectiveness all play a role in the character of environmental care. As a result, advanced knowledge is expected to foster the character of environmental stewardship. Other research has found that environmental knowledge has a significant positive effect on environmental attitudes, environmental attitudes have a significant positive effect on environmental, behavioral intentions, and pro-environmental behavior, and environmental behavior intentions have a significant positive effect on proenvironmental behavior (Liu et al., 2020).

Then, by 9.4 percent, for the influence of demographic factors (gender and age) on the character of caring for the environment. Gender influences a person's behavior in his environment, according to Pronityastuti (2017), There were also significant differences with 
regard to specific factors influencing pro-environmental behavior, namely gender (Molina et al., 2018). According to the findings of this study, female students have higher environmental care character values than male students. This is consistent with the findings of Pronityastuti (2017), who claims that women have more pro-environmental attitudes, concerns, and behaviors than men. According to another study conducted by Pronityastuti (2017: 23), demographic factors such as education, gender, age, income, and place of residence have a significant direct correlation to the character of environmental stewardship. In line with this, Ifegbesan and Rampedi (2018) discovered that age and attitudes have a significant relationship with environmental sustainability problems.

Environmental attitudes and behaviors are at the heart of a sustainable future, but little is known about their early childhood developmental origins Otto et al (2019) is the first longitudinal study to look at how children's environmental attitudes and behaviors change throughout their childhood (ages 7 to 18). Around the age of seven, the form of environmental attitudes and behavior increased until the age of ten, leveled off until the age of fourteen, and then decreased again. Environmental behavior develops from childhood to early adolescence and begins to consolidate around the age of ten, whereas environmental attitudes continue to change until at least early adulthood.

Another finding shows that children who attend primary schools that are designed to engage them in sustainable design have significantly more pro-environmental attitudes and behaviors. As a result, it is proposed that an environmental education pedagogy be developed that involves children directly in learning sustainable design features such as solar panels, recycled water use, natural lighting, gardens, and outdoor classrooms. (Tucker \& Izadpanahi, 2017). The findings of this study are also consistent with Azwar (2006)'s belief that age is one of the factors that determine a person's maturity in thinking and learning. Maturity of thought can influence knowledge, attitude, and practice.

\section{CONCLUSION}

Knowledge of issue has a significant influence on the environmental care character of students in Lab School Elementary School, Faculty of Education, Muhammadiyah University Jakarta by 4.4 percent, and demographic factors (gender and age) have a significant influence on the environmental care character of students in Lab School Elementary School, Faculty of Education, Muhammadiyah University Jakarta by 9.4 percent. As a result, demographic factors (gender and age) have a greater influence on the environmental care character of students at the school than knowledge of the issue. This study has limitations, such as the fact that the participants were only elementary school students. As a result, more research can be done to develop a variety of interesting media and teaching materials to help people understand the importance of environmental stewardship. The findings have an impact on public awareness of the importance of environmental stewardship.

\section{REFERENCES}

Aryogi, I., \& Wulansari, D. (2016). Subjective Well-being Individu dalam Rumah Tangga Di Indonesia. Jurnal IImu Ekonomi Terapan, 1(1), 1-12. https://doi.org/10.20473/jiet.v1i1.1900

Azwar. 2006. Sikap Manusia, Teori dan Pengukurannya edisi ke-2. Yogyakarta : Pustaka Pelajar

Fua, J. La. (2014). Aktualisasi Pendidikan Islam Dalam Pengelolaan Lingkungan Hidup Menuju Kesalehan Ekologis. Jurnal Al-Ta'dib, 7(1), 19-36.

Harahap, R. Z. (2015). Etika Islam dalam Mengelola Lingkungan Hidup. EDUTECH: Jurnal IImu 
Pendidikan Dan Ilmu Sosial, 1(01).

Ifegbesan, A. P., \& Rampedi, I. T. (2018). Understanding the role of socio-demographic and geographical location on pro-environmental behavior in Nigeria. Applied Environmental Education and Communication, 17(4), 335-351. https://doi.org/10.1080/1533015X.2017.1419102

Kaiser, F. G., Wölfing, S., \& Fuhrer, U. (1999). ENVIRONMENTAL ATTITUDE AND ECOLOGICAL BEHAVIOUR. Journal of Environmental Psychology, 19(1), 1-19. https://doi.org/https://doi.org/10.1006/jevp.1998.0107

Liu, P., Teng, M., \& Han, C. (2020). How does environmental knowledge translate into proenvironmental behaviors?: The mediating role of environmental attitudes and behavioral intentions. Science of The Total Environment, 728, 138126. https://doi.org/https://doi.org/10.1016/j.scitotenv.2020.138126

Narut, Y. F., \& Nardi, M. (2019). Analisis Sikap Peduli Lingkungan Pada Siswa Kelas VI Sekolah Dasar di Kota Ruteng. Scholaria: Jurnal Pendidikan Dan Kebudayaan, 9(3), 259-266. https://doi.org/10.24246/j.js.2019.v9.i3.p259-266

Otto, S., Evans, G. W., Moon, M. J., \& Kaiser, F. G. (2019). The development of children's environmental attitude and behavior. Global Environmental Change, 58, 101947. https://doi.org/https://doi.org/10.1016/j.gloenvcha.2019.101947

Palupi, T., \& Sawitri, D. R. (2017). Hubungan Antara Sikap Dengan Perilaku Pro-Lingkungan Ditinjau dari Perspektif Theory Of Planned Behavior Relationship Between Attitude And Pro-Environmental Behavior from the Perspective of Theory of Planned Behavior Perilaku Pro-Lingkungan. Proceeding Biology Education Conference, 14, 214-217.

Pronityastuti, M. (2017). The Effect of Gender Differences on Pro Environmental Behavior in Directorate General Binapenta\&pkk, Ministry of Manpower, 2016. Jurnal Ilmiah Pendidikan Lingkungan Dan Pembangunan, 18(1), 21-27.

Purba, E. S., \& Yunita, S. (2017). Kesadaran Masyarakat dalam Melestarikan Fungsi Lingkungan Hidup. Jupiis: Jurnal Pendidikan IImu-IImu Sosial, 9(1), 57. https://doi.org/10.24114/jupiis.v9i1.6461

Tucker, R., \& Izadpanahi, P. (2017). Live green, think green: Sustainable school architecture and children's environmental attitudes and behaviors. Journal of Environmental Psychology, 51,

209-216. https://doi.org/https://doi.org/10.1016/j.jenvp.2017.04.003

Molina, Vicente, M. A., Fernández-Sainz, A., \& Izagirre-Olaizola, J. (2018). Does gender make a difference in pro-environmental behavior? The case of the Basque Country University students. Journal of Cleaner Production, 176, 89-98. https://doi.org/https://doi.org/10.1016/j.jclepro.2017.12.079

Wiryono, W. (2013). Pengantar Ilmu Lingkungan. Pertelon Media. 